\title{
探索景观建筑在园林设计中的应用
}

\author{
严登
}

宁波宁景生态园林有限公司，浙江 宁波 315000

[摘要]在社会经济快速发展的影响下，使得民众的生活质量得到了显著的提升，人们的思想意识也出现了明显的变化，对精 神方面的需求在逐渐的提升。园林设计效果的不断提升使得人们的精神需求在逐渐的被满足, 利用良好的景观建筑, 促进城 市美化工作的不断发展进步。在开展园林设计工作的时候, 运用最前沿的设计理念以及设计技术来带动园林景观设计质量的 不断提升, 最终更加高效的满足民众的精神需要, 并且充分的将城市园林设计的作用施展出来。其次, 园林设计工作人员要 切实的运用景观建筑来对风景艺术效果加以呈现, 并且要重视景观建筑与园林设计的完美融合, 最终将园林设计的核心理念 加以呈现。这篇文章主要围绕景观建筑在园林设计中的切实运用展开全面的分析研究, 希望对景观建筑的健康稳定发展有所 助益。

[关键词]景观建筑; 精神追求; 园林; 设计

DOI: $10.33142 /$ aem.v1i3.969

中图分类号: TU986

文献标识码：A

\section{Exploring the Application of Landscape Architecture in Garden Design}

YAN Deng

Ningbo Ningjing Ecological Garden Co., Ltd., Ningbo, Zhejiang, 315000, China

\begin{abstract}
Under the influence of the rapid development of social economy, the quality of life of the people has been significantly improved, people's ideology has also undergone significant changes, and the demand for spiritual aspects is gradually improving. The continuous improvement of garden design effects has gradually satisfied people's spiritual needs, using good landscape architecture to promote the continuous development and progress of urban beautification work. In the development of garden design work, the use of cutting-edge design concepts and design techniques to promote the continuous improvement of the quality of landscape design, and ultimately more effectively meet the spiritual needs of the people, and fully play the role of urban garden design. Secondly, the garden design staff should use the landscape architecture to present the landscape art effect, and pay attention to the perfect integration of the landscape architecture and the garden design, and finally present the core concept of the garden design. This article focuses on the practical application of landscape architecture in landscape design, and hopes to contribute to the healthy and stable development of landscape architecture.
\end{abstract}

Keywords: landscape architecture; spiritual pursuit; garden; design

\section{引言}

在园林设计领域中, 景观建筑在园林设计中占据着重要的地位, 只有将景观建筑充分融入整个园林设计当中, 才 能做出完美令人赏心悦目的园林。一个有着鲜明特色的园林建筑, 往往决定人们对于一个园林设计的整体印象评价高 低。园林建筑往往被当作一个成功园林的标志性建筑, 园林建筑作为一种人文建筑景观, 它的艺术性表现只有与园林 自身的文化背景相结合, 才能更好地彰显自然与人文的有机结合, 升华园林的整体设计。

\section{1 景观建筑的独特性及其设计特征}

\section{1 园林设计中的景观建筑}

景观建筑通常可以划分为两种类型, 即: 观赏小品以及景观建筑。其中观赏小品其涉及到各种类型的盆栽, 小规 模的景观以及装饰物 ${ }^{[1]}$ 。利用景观自身具有的艺术感来营造良好的环境氛围, 给人们带来美的享受。就现如今园林设计 情况来说, 园林景观往往会设计多个景观建筑小品, 有效的充实了园林景观的美感, 每一个建筑观赏小品都具备独一 无二的艺术气息, 并且往往都承载了一些传统园林设计的理念, 融合了当下民众生活的实际需要以及最前沿的审美观 念。将一些现代的建筑风格元素运用到传统建筑项目之中, 能够起到画龙点睛的效果, 并且设计工作人员可以结合自 身对艺术美的认识将当代设计理念切实的运用到园林景观设计之中, 在现代园林景观设计的质量和效率的保证上面会 起到积极的影响作用。

\section{2 园林景观建筑的设计特征}

景观建筑是园林设计中最为关键的一个部分, 其包含了大量的园林景观的精髓, 所以景观建筑通常都具有独一无 二的特点, 在实施园林设计工作的时候务必要充分的结合园林所处地区的地质特征以及人文文化, 更好的保证园林景 观的设计效果 ${ }^{[2]}$ 。在实施园林项目设计工作的时候, 景观建筑的设计质量和效果的作用是十分巨大, 集中表现在下面两 
个层面:

首先, 在针对园林内部景观布局进行设计以及对景观建筑的整体效果进行设计工作的时候, 务必要充分联系园林 景观所处地区的实际情况，秉承因地制宜的原则，将园林设计的作用更好的发挥出来。

其次, 在针对园林空间结构实施设计的时候, 要在确保质量和效果的基础上, 重视景观建筑与周边环境之间的联系。 促进园林景观能够与自然环境保持统一性, 更好的促进园林设计整体艺术性的提升。要想更好的将景观建筑在园林景观 的感染力发挥出来, 务必要做到将景观建筑与园林设计的融合如同诗画的融合一样, 才能更好的提升景观的艺术性。

\section{2 景观建筑在园林设计当中的应用}

\section{1 构思和应用具体分析}

景观建筑设计工作正式开始之前, 需要进行前期的构思准备, 并要实施现场勘查工作。通常构思的过程主要集中 在下面两个层面: 首先, 园林设计所针对的景观建筑要与园林项目整体所要呈现出来的艺术美保持一致, 要从这一方 面入手进行构思, 景观建筑工程施工务必要保证与园林的性质相统一, 对景观建筑进行合理的布控, 更好的促进园林 整体美感的提升。其次, 全面的挖掘出景观建筑的总体性能, 设计工作人员需要针对园林性质, 适当的设计部分功能 性建筑, 促使园林整体更具人情味, 充分的表现出人性化的特点, 让游客产生一种归属感, 并且能够将园内所有的资 源进行高效的利用, 最大限度的提升园林的价值, 对于园林设计效果的提升也是非常有助益的 ${ }^{[3]}$ 。

\section{2 凉亭设计}

在针对园林景观开展设计工作的时候, 凉亭是最为普通并且十分常见的基础景观。凉亭不但具备良好的人文艺术 性质, 并且能够为游客提供休息娱乐的空间。通常情况下, 凉亭所选择的位置往往都会设计在园林景观的里面, 并且 在实施设计凉亭设计工作的时候, 需要结合现场实际情况来加以设计。普通凉亭结构大部分都是以多角形或者是梅花 形为主, 在凉亭结构的顶层往往都会设计屋檐结构, 屋檐结构的形式可以结合凉亭整体结构形式来加以确定。就当代 凉亭来说, 主要以平面图形, 破面形或者是弧形为最基本的结构形式。凉亭结构的建造物料大部分都以石料, 木料以 及钢筋混凝土为主。凉亭顶层往往会被设计一些表现当地文化的图案, 并且要结合凉亭周边环境进行设计。凉亭结构 形式多样, 但是总体上都具备精巧, 高雅的特点, 为游客营造一种宫廷仙境的感觉。这也充分的说明了, 凉亭在园林 景观中的作用是十分巨大的。诸如: 在国内的某一地区, 在针对公园内部实施凉亭景观设计工作的时候, 设计人员选 择了四角形为主体结构的形状, 屋顶设计成三层屋檐的结构形式, 连接屋顶地面的支撑主体整体设计为红色, 凸显出 一种宏伟壮观的艺术美。凉亭内部为了增添实用性, 设置了长方形以及圆柱形的缓台, 能够为游客休息提供便利。在 整个公园内, 设计了四个凉亭, 每两个凉亭直接相连, 在凉亭附近建造了一个荷塘, 荷塘中有流水, 并种植了一些荷 花, 当游客游玩到此的时候, 可以在凉亭中休息欣赏荷花美景 ${ }^{[4]}$ 。

\section{3 桥的设计以及施工}

建筑园林与河流是最佳搭配, 针对国内诸多园林进行统计我们发现, 所有的著名园林景观周边都会设计河流与之 配合, 正是因为这样, 桥梁结构的作用更加的凸显出来。这主要是因为水流能够对天气起到良好的调节作用, 并且可 以保证空气中的湿润度。但是想要保证游客能够与河流进行深入的接触, 最为重要的是要对桥梁结构加以运用。大型 园林中的代表性桥梁设计, 以杭州西湖的 “断桥” 最为著名。这座古桥拥有着独特的位置与造型, 让人一眼看见便无 法轻易忘记, 并且使得游客即使只是站在断桥上, 就能够欣赏大半西湖的优美景色, 是园林景观设计的经典之作。

\section{4 楼阁的设计}

楼阁在景观建筑中可以算是大型景观建筑之一了, 但是其在现实中却并不常见, 其主要原因是楼阁的造价以及占 地面积过大, 并且在后期的维修以及保养方面花费成本过高, 但不可否认的是, 楼阁本身具有巨大的价值, 楼阁不仅 可以为人们提供欣赏景色的良好视野空间, 同时由于中国自古信佛的传统, 楼阁也可以供奉佛像等, 为人们提供一个 祈福的场所 ${ }^{[5]}$ 。

\section{3 结语}

综合以上阐述我们总结出, 景观建筑在园林设计中的作用是十分巨大的, 其不但能够提升园林整体的美感, 并且 在保证园林设计效果方面也可以起到积极的影响作用。想要将园林设计工作的作用彻底的施展出来, 最为重要的是结 合实际情况将动态景观与静态景观充分的融合在一起, 达到净化心灵和满足精神需求的目的。

\section{[参考文献]}

[1]李宇波.景观建筑在园林设计中的应用浅述 [J]. 山西建筑, 2019,45 (01) : 183-185.

[2] 梁惠,刘琳. 景观建筑在园林设计中的应用 $[\mathrm{J}]$. 现代园艺, 2018(18): 123 .

[3]王勇.景观建筑在园林设计中的应用解析 $[\mathrm{J}]$. 现代园艺,2018(08): 92 .

$[4]$ 余茂军,张林. 景观建筑在园林设计中的应用分析 $[\mathrm{J}]$. 现代园艺, 2017 (16): 57.

[5]冯驱斐. 景观建筑在园林设计中的应用分析 $[J]$. 现代园艺, 2017 (10): 57 .

作者简介: 严登(1977.2-), 男, 高级工程师, 浙江宁波, 主要从事风景园林设计施工及管理。 